[VOL. XXVI, NO. 2

\title{
A COMMENT ON ITO LTD. v. MIDA ELECTRONICS INC. - THE SUPREME COURT OF CANADA, PRIVITY OF CONTRACT AND THE HIMALAYA CLAUSE
}

\author{
LINDA C. REIF*
}

\section{INTRODUCTION}

In the transportation of goods by sea, the shipper contracts with a marine carrier usually agreeing to a term limiting the liability of the carrier for damage to or loss of the goods. The contract of carriage between the shipper and the marine carrier is evidenced by a bill of lading which contains its terms.' Pursuant to legislation, the consignee named in the bill of lading also will be bound by its terms and will be subject to any exclusion clauses therein. ${ }^{2}$

Due to the nature of the shipment, the carrier often contracts with other persons, such as the stevedore, to obtain assistance in performance of the contract of carriage. If the stevedore has negligently damaged the goods, the owner has sued the stevedore in tort. Contrary to the doctrine of privity of contract, the stevedore has claimed the benefit of the exemption clause in the bill of lading. Initially the tactic failed, leading to the development of the Himalaya clause. A Himalaya clause ${ }^{3}$ is a limitation or exclusion of liability clause contained in a bill of lading that is drafted to extend its coverage beyond the carrier to include, in addition, servants, agents, independent contractors and other third parties employed by the carrier in the performance of the contract of carriage.

In ITO - International Terminal Operators Ltd. v. Miida Electronics Inc.,${ }^{4}$ the Supreme Court of Canada has finally been given the opportunity

- Assistant Professor, Faculty of Law, University of Alberta. The Author wishes to thank Professor D. Percy for his helpful comments.

1. The bill of lading fulfills three functions: (1) it is a receipt for the delivery of the goods to the carrier for shipment; (2) it is a document of title to the goods, transfer thereof affected by its endorsement and delivery; and (3) it is evidence of the terms of the contract of affreightment between the shipper/consignor and the carrier. See, e.g. Re Ardennes [1951] 1 K.B. 55; Pyrene Co. Ltd. v. Scindia Navigation Co. Ltd. [1954] 2 Q.B. 402; Anticosti Shipping Co. v. St. Amand [1959] S.C.R. 372. Cf. Union Industrielle et Maritime v. Petrosul International Ltd. (1984) 26 B.L.R. 309 (F.C.T.D.); St. Lawrence Const. Ltd. v. Fed. Comm. \& Navigation Co. Ltd. (1985) 56 N.R. 174 (Fed. C.A.); Scrutton on Charterparties and Bills of Lading (19th ed. Sir A. Mocatta, et al. eds. 1984) at 54-57.

2. See, e.g., Bills of Lading Act, R.S.C. 1970, c. B-6, s. 2; Mercantile Law Amendment Act, R.S.O. 1980 , c. 265 , s. 7 .

3. The term was drawn from the name of the vessel, the "Himalaya", in Adler v. Dickson [1955] 1 Q.B. 158. See 1 Carver's Carriage By Sea (13th ed. R. Colinvaux ed. 1982) at 256.

4. ITO - International Terminal Operators Ltd. v. Miida Electronics Inc. [1986] 1 S.C.R. 752, 28 D.L.R. (4th) 641; rev'g in part (sub nom. Miida Electronics Inc. v. Mitsui O.S.K. Lines Ltd.) [1982] 1 F.C. 406, 37 N.R. 396, 124 D.L.R. (3d) 33 (C.A.); revg in part (sub nom. Marubeni America Corp. v. Mitsui O.S.K. Lines Ltd.) [1979] 2 F.C. 283, 96 D.L.R. (3d) 518 (T.D.). 
to determine the effectiveness of a Himalaya clause in a bill of lading under Canadian maritime law. The decision sanctions its operation, putting the imprimatur of the Supreme Court on the device of the agency construction which is used to surmount the privity of contract barrier. The decision settles a period of uncertainty in the Canadian judicial system which had lingered after other Commonwealth states had accepted the validity of the Himalaya clause within their respective jurisdictions. ${ }^{5}$ Moreover, the ITO Ltd. case clarifies the jurisdiction of the Federal Court in admiralty and demonstrates the approach of the Supreme Court to the construction of an operative exemption clause in a commercial contract. The resolution of the main issues evidences an appreciation of the flexibility that is required of the law in relation to international trade and commerce. However, this Comment will illustrate that although the acceptance of the validity of the Himalaya clause can be justified on a pragmatic basis, its application in the ITO Ltd. decision can be criticized.

\section{THE POSITION OF THE STEVEDORE}

Due to the international character of the contract of affreightment, the provisions of the bill of lading have been regulated by treaty. Conventions currently in force are the Hague Rules, ${ }^{6}$ as amended by the Visby Rules. Although the Visby Rules extend the defences and limitations of liability granted to the carrier in the Hague Rules to its servants or agents, the independent contractor, typically the stevedore, is excluded from this protection. States which are parties to the earlier treaty alone, or to both, have enacted domestic legislation to implement their particular international obligations. ${ }^{8}$ This development was a realistic accommodation of the conflicting interests involved in the contract. Commercial practicality mandated the insertion of clauses limiting the carrier's liability for damage to, or loss of, the goods based on the most efficient allocation of risk, responsibility for obtaining insurance coverage and cost. ${ }^{9}$ However, when the owner of goods successfully sued the third party stevedore in tort the

5. New Zealand Shipping Co. Ltd. v. A.M. Satterthwaite \& Co. Ltd. ("The Eurymedon") [1975] A.C. 154, [1974] 1 All E.R. 1015 (P.C.); Port Jackson Stevedoring Pty. Ltd. v. Salmond \& Spraggon (Australia) Pty. Ltd. ("The New York Star") [1981] 1 W.L.R. 138, [1980] 3 All E.R. 257 (P.C.), [1980] 2 Lloyds Rep. 317; also see Godina v. Patrick Operations Pty. Ltd. [1984] 1 Lloyd's L.R. 333 (N.S.W. C.A.). In the U.S.A. see, e.g. Tessler Bros. (BC) Ltd. v. Italpacific Line and Matson Terminals Inc. [1975] 1 Lloyd's Rep. 210 (C.A. 9th Cir.). See discussion, infra, text accompanying footnotes 41-62.

6. The International Convention for the Unification of Certain Rules of Law Relating to Bills of Lading, signed at Brussels, August 25, 1924, 120 L.N.T.S. 155, (1931) U.K.T.S. 17.

7. Protocol to amend the 1924 International Convention for the Unification of Certain Rules of Law Relating to Bills of Lading, signed at Brussels, February 23, 1968, (1977) U.K.T.S. 83. See, e.g. Art. 3 r. 1 which gives the carrier the benefits of the defences and limits of liability in the Hague Rules whether an action against it be founded in contract or in tort, and Art. 3 r. 2 which extends the benefit of the defences and limits of liability granted to the carrier in the Hague Rules to the servant or agent of the carrier ". . . such servant or agent not being an independent contractor ..."

8. Canada is not a party to either treaty. Regardless, the Schedule to The Carriage of Goods By Water Act, R.S.C. 1970, c. C-15 duplicates the provisions of the Hague Rules. See W. Tetley, Marine Cargo Claims (2nd ed. 1978).

9. See S. Waddams, Comment (1977) 55 Can. Bar Rev. 327; M. Tedeschi, "Consideration, Privity \& Exemption Clauses" (1981) S5 Aust. L.J. 876. 
allocation of risk and cost in the contract of carriage was circumvented. In the absence of international or domestic regulation extending the carrier's protection to the stevedore, ${ }^{10}$ the stevedore attempted to absolve itself of liability by claiming the protection of the exemption clause in the contract of carriage. Until the Himalaya clause was created and its wording refined, the stevedore was barred from taking this path by the privity of contract principle."

\section{PRIVITY OF CONTRACT}

In 1861, Tweddle v. Atkinson ${ }^{12}$ adopted the doctrine which was later confirmed by the House of Lords in Dunlop Pneumatic Tyre Co. Ltd. v. Selfridge \& Co. Ltd. ${ }^{13}$ In the latter decision Viscount Haldane L.C. stated, "... in the law of England certain principles are fundamental. One is that only a person who is a party to a contract can sue on it. Our law knows nothing of a jus quaesitum tertio arising by way of contract."' ${ }^{4}$ The doctrine of privity has been upheld consistently in subsequent Anglo-Canadian caselaw. ${ }^{\text {Is }}$ Thus, a contract made for the benefit of or attempting to impose an obligation on a third party cannot be enforced by or against the stranger to the contract.

Yet many exceptions to the doctrine of privity of contract have been created. In the realm of the law of real property, exceptions developed in contracts for the sale or lease of land. ${ }^{16}$ Various statutory exemptions can be found. ${ }^{17}$ There is the problematic claim that the irrevocable letter of

10. The U.N. Convention on the Carriage of Goods By Sea ("Hamburg Rules"), concluded at Hamburg, March 31, 1978, U.N. Doc. A/CONF. 89/5; (1978) 17 I.L.M. 608, signed by a number of states but not yet in force, updates and will replace the Hague-Visby Rules. The Hamburg Rules, Art. 7, r. 2 extend the defences and limits of liability granted to the carrier therein to a servant or agent of the carrier "... if he proved that he acted within the scope of his employment ..." The independent contractor is not expressly mentioned and so, even if the Rules come into force they would not appear to protect such an entity. See $\mathrm{H}$. Kindred, et al., The Future of Canadian Carriage of Goods By Water Law (Dalhousie Ocean Studies Programme 1982) at 20-23.

11. See Adler v. Dickson, supra, footnote 3 and Midland Silicones Ltd. v. Scruttons Ltd. [1962] A.C. 446, [1962] 1 All E.R. 1 (H.L.) as early examples where the exclusion clause was not yet in the Himalaya clause format. In contrast, the third party was permitted to benefit from the protection of the Himalaya clause as drafted in New Zealand Shipping Co. Ltd. v. A.M. Satterthwaite \& Co. Ltd. ("The Eurymedon"), supra, footnote 5. See infra, text accompanying footnotes 41 to 62 .

12. (1861), 1 B. \& S. 393; 121 E.R. 762.

13. [1915] A.C. 847 (H.L.).

14. Id. at 853 .

15. E.g. Midland Silicones Ltd. v. Scrutton Ltd., supra, footnote 11; Beswick v. Beswick [1968] A.C. 58, [1967] 2 All E.R. 1197 (H.L.); Can. General Electric Co. Ltd. v. Pickford \& Black Ltd. (The "Lake Bosomtwe") [1971] S.C.R. 41, 14 D.L.R. (3d) 372; "The Eurymedon", supra, footnote 5; Greenwood Shopping Plaza Ltd. v. Beattie [1980] 2 S.C.R. 228, 111 D.L.R. (3d) 257, 10 B.L.R. 234. See also S. Waddams, The Law of Contracts (2nd ed. 1984), ch. 9; Ontario Law Reform Commission, Report on Amendment of the Law of Contract (1987), pp. 49-71.

16. E.g., the equitable doctrine of restrictive covenants with respect to the use of land; such covenants could be enforced not only against the original contracting party but also in certain instances, against persons who succeeded in title. Tulk v. Moxhay (1848) 2 Ph. 774, 41 E.R. 1143. See, G. Fridman, The Law of Contract in Canada (2nd ed. 1986).

17. See, e.g., Insurance Act, R.S.O. 1980, c. 218, s. 172; Bills of Exchange Act, R.S.C. 1970, c. B-5, s. 57. Also see the bills of lading statutes, supra, footnote 2 and the law of assignment, infra, footnote 21 . 
credit is another exception to the rule, born out of international commercial practice. ${ }^{18}$ The finding of a duty of care in tort owed by a contracting party to the third party can also avoid its strictures. But the doctrine remains, a pillar supporting the Anglo-Canadian law of contract. Its scope depends upon the definition given to an entity that is a contracting party. ${ }^{19}$ Various legal devices have been used to manoeuvre around the practical effects of the doctrine by characterizing a person who would otherwise be a stranger as a contracting party thereby leaving the conceptual barrier of privity of contract intact. The use of the trust, ${ }^{20}$ the law of assignment ${ }^{21}$ and the doctrine of agency ${ }^{22}$ have all been used for this purpose.

The agency relationship is the method implemented in the Himalaya clause caselaw. ${ }^{23}$ The stevedore is classified as the principal on whose behalf the carrier, as agent, contracts with the shipper in the contract of carriage. However, the agency invention does not apply to the whole contract as the carrier is contracting as agent only with respect to the exemption clauses therein. Generally, in an agency relationship the agent may have the authority of its principal to contract with other persons on behalf of the principal. Indeed, the contract is deemed made between the principal and the other contracting party with the result that it can be enforced both by and against the principal. ${ }^{24}$

18. The instructions to issue an irrevocable letter of credit given by the buyer to its bank constitutes a contract between them. The seller, the beneficiary of the credit, is a third party thereto yet caselaw has upheld the principle that the bank is under an absolute obligation to pay the seller on provision of the stipulated documents, absent fraud, despite any dispute over payment raised by the buyer. See, e.g. Hamzeh Malas \& Sons v. British Imex Industries Ltd. [1958] 2 Q.B. 127, [1958] 1 All E.R. 262 (C.A.); United City Merchants (Invts.) Ltd. v. Royal Bank of Canada ("The American Accord") [1982] 2 W.L.R. 1039, [1982] 2 All E.R. 720 (H.L.). However, it is argued that this is not really an exception to the doctrine of privity. See Anson's Law of Contract (26th ed. A.G. Guest ed. 1984) at 376 and The American Accord, id. at 1044, ". . . there are four autonomous though interconnected contractual relationships involved . ..", per Lord Diplock.

19. E.g., Beswick v. Beswick, supra, footnote 15; Gasparini v. Gasparini (1978) 87 D.L.R. (3d) 282 (Ont. C.A.) where the administratrix of the estate of a deceased contracting party was permitted to enforce the contract in her capacity as administratrix, notwithstanding that the contract was made partly for her personal benefit. The doctrine of privity was maintained by the assertion that the administratrix would not be permitted to enforce the contract in her personal capacity.

20. The equitable device of the trust of contractual rights. "Where a contract is made for the benefit and on behalf of a third person, there is an equity in that third person to sue on the contract and the person who has entered into the contract may be treated as a trustee for the person for whose benefit it has been entered into", per Fry L.J. in Lloyds v. Harper (1880) 16 Ch. D. 290 (C.A.), at 309. However, since Re Schebsman [1944] Ch. 83, [1943] 2 All E.R. 768 (C.A.) the courts have been reluctant to find a trust unless an intention to create one is clearly evident from the language used and the circumstances.

21. See, e.8., Conveyancing and Law of Property Act, R.S.O. 1980, c. 90, s. 53, with similar statutory provisions in other provinces. Also see S. Waddams, supra, footnote 15, ch. 8 for discussion of equitable assignment.

22. See, e.g., Bowstead on Agency (15th ed. F.M.B. Reynolds ed. 1985); G.H.L. Fridman, The Law of Agency (5th ed. 1983).

23. See infra, text accompanying footnotes 41 to 62 .

24. Supra, footnote 22. 


\section{THE ITO LTD. CASE}

\section{A. THE FACTS}

Despite the intricacy of the legal issues involved in the ITO Ltd. case, the underlying facts are straightforward. The respondent marine carrier, Mitsui O.S.K. Lines Ltd. (Mitsui), entered into a contract evidenced by a bill of lading for the shipment of 250 cartons of electronic calculators from Kobe, Japan to Montreal. The other party to the contract was the owner of the goods, the respondent Miida Electronics Inc. (Miida). Under the contract Miida remained the owner of the goods and was designated as the consignee taking delivery of them in Montreal. The carrier, Mitsui, previously had entered into a contract with the appellant, a stevedoring company and terminal operator named International Terminal Operators Ltd.(ITO). Under this contract, ITO agreed to unload and discharge goods from Mitsui's vessels and then store them in the Port of Montreal until the consignee took delivery of them.

In performance of the contract of carriage between Mitsui and Miida, the goods arrived in Montreal on one of Mitsui's vessels. Pursuant to the stevedoring-terminal services contract between ITO and Mitsui, ITO discharged the goods and stored them in a leased terminal transit shed located in the Port area. Unfortunately, thieves broke into the shed and stole at least one third of the calculators. ${ }^{25}$ The guards of the security service employed by ITO missed a security check scheduled at that time; the thieves were able to gain entry to the shed because the padlock that usually locked the door had not been attached.

The bill of lading excluded the liability of the carrier Mitsui in clause 8 and in clause 18 , both provided in part, as follows:

8 The carrier shall not be liable in any capacity whatsoever for any delay, nondelivery, mis-delivery or loss of or damage to or in connection with the goods occurring before loading and/or after discharge, whether awaiting shipment landed or stored ...26

18 .... In any case the carrier's responsibility shall cease at the time when the goods are discharged from the vessel and in any case all risks and expenses (including expenses for landing, lighterage, storage, cartage, port charges, etc.) incurred by delivery otherwise than from the vessel's side shall be borne by shipper and/or consignee ... .27

The bill of lading also contained a Himalaya clause in clause 4 whereby Mitsui sought to extend its exemption clauses to entities it used in the performance of the contract. It stated: $:^{28}$

4 It is expressly agreed between the parties hereto that the master, officers, crew members, contractors, stevedores, longshoremen, agents, representatives, employees or others used, engaged or employed by the carrier in the performance of this contract, shall each be the beneficiaries of and shall be entitled to the same, but no further exemptions and immunities from and limitations of liability which

25. Mclntyre J. stated, supra, footnote 4 at p. 757, that 169 of the 250 cartons of calculators were stolen. However, at p. 762, in the admissions filed with the trial court by the parties it was stated that of the 250 cartons each containing two sets, 169 sets of calculators, being 84.5 cartons, were not delivered to Miida in Montreal.

26. Supra, footnote 4 , at $758-759$.

27. Id. at 759.

28. Id. at 758 . 
the carrier has under this bill of lading whether printed, written, stamped thereon or incorporated by reference. The master, officers, crew members and the other persons referred to heretofore shall to the extent provided be or be deemed to be parties to the contract in or evidenced by this bill of lading and the carrier is or shall be deemed to be acting as agent or trustee on behalf of and for the benefit of all such persons.

In the stevedoring-terminal services contract between Mitsui and ITO (the Contractor), clauses 2 and 7 were relevant to the dispute. Clause 2 stated that ITO would load and discharge the vessels of Mitsui and in the event that watching services were required, ITO would arrange such services as agent for Mitsui on the condition that ITO excluded its liability for, inter alia, theft of the cargo. Clause 7 limited ITO's responsibility by providing in part (emphasis added): ${ }^{29}$

$7 \quad$... the Contractor's responsibility for damage or loss shall be strictly limited to damage to the vessel and its equipment and physical damage to cargo or loss of cargo overside through negligence of the Contractor or its employees .... It is further expressly understood and agreed that the Company will include the Contractor as an express beneficiary, to the extent of the services to be performed hereunder, of all rights, immunities and limitation of liability provisions of all contracts of affreightment as evidenced by its standard bills of lading and/or passengers' tickets, issued by the Company during the effective period of this agreement...

\section{B. THE PROCEEDINGS}

Miida initiated an action in the Federal Court, Trial Division, suing both Mitsui and ITO jointly and severally. ${ }^{30}$ The claim against Mitsui was based on breach of the contract of carriage. The claim against ITO was based principally on delict or quasi-delict. Miida argued that ITO had been negligent in failing to take the proper steps to prevent the theft of the goods committed to its care. The Trial Division, in a judgment given by Marceau J., dismissed the action against both defendants.

Miida appealed the entire judgment. A majority of the Federal Court of Appeal, Le Dain J. and Lalande D.J., allowed Miida's appeal against ITO. In contrast, Miida's appeal against Mitsui was dismissed by a majority of the Federal Court of Appeal. ${ }^{31}$ Neither ITO nor Miida were satisfied; ITO appealed the decision with respect to its liability for negligence and Miida appealed the dismissal of its claim against the carrier Mitsui.

\section{THE ISSUES}

In a four-three majority opinion given by McIntyre J., Dickson C.J.C., Estey and Wilson JJ. concurring, the Supreme Court of Canada addressed two issues: ${ }^{32}$

"1. The general question of jurisdiction of the Federal Court in admiralty. This will involve a consideration of the extent of Canadian maritime law.

2. The effect of the Himalaya clause in the bill of lading."

29. Id. at 760.

30. Marubeni America Corp. v. Mitsui O.S.K. Lines Ltd. (F.C.T.D.), supra, footnote 4.

31. Supra, footnote 5. Also see, infra, text accompanying footnotes 41 to 62 .

32. Supra, footnote 4 at 766 . 
[VOL. XXVI, NO. 2

\section{JURISDICTION OF THE FEDERAL COURT}

The issue pertained to Miida's claim against ITO alleging negligent storage of Miida's goods after discharge. The majority decided that the Federal Court did have the jurisdiction to hear the claim.

McIntyre J. implemented a tripartite test for the decision whether the Federal Court can exercise its jurisdiction in a particular case based on the requirements generally established in Quebec North Shore Paper Co. v. Canadian Pacific Ltd. ${ }^{33}$ and followed in McNamara Const'n (Western) Ltd. v. The Queen. ${ }^{34} \mathrm{He}$ stated: ${ }^{35}$

"1. There must be a statutory grant of jurisdiction by the federal Parliament.

2. There must be an existing body of federal law which is essential to the disposition of the case and which nourishes the statutory grant of jurisdiction.

3. The law on which the case is based must be "a law of Canada" as the phrase is used in s. 101 of the Constitution Act, 1867"

The first requirement was found to be satisfied by sections 2 and 22(1) of the Federal Court Act. ${ }^{36}$ The decision of Laskin C.J.C. in Tropwood A.G. v. Sivaco Wire and Nail Co.,$^{37}$ that the Federal Court has the jurisdiction to adjudicate on matters of admiralty law, as being within the ambit of $\mathbf{s .} 2$ "Canadian maritime law" and s. 22 of the Federal Court Act, was instrumental in reaching this conclusion.

In holding the second requirement had also been met, it was decided that s. 22 (1) "... Canadian maritime law or any other law of Canada relating to any matter coming within the class of subject of navigation and shipping .. " was a body of federal law which was essential to the disposition of the case and which nourished the statutory grant of jurisdiction. The majority decided that Miida's claim against ITO could only come within the second half of the definition of "Canadian maritime law" in s. 2 of the Federal Court Act being the law that "... . would have been so administered if that court had had on its Admiralty side unlimited jurisdiction in relation to maritime and admiralty matters ..." The majority, in the first interpretation of this phrase, construed it liberally, stating: ${ }^{38}$

"... the words "maritime" and "admiralty" should be interpreted within the modern context of commerce and shipping. In reality, the ambit of Canadian maritime law is limited only by the constitutional division of powers in the Constitution Act, 1867. I am

33. [1977] 2 S.C.R. 1054, 9 N.R. 471, 71 D.L.R. (3d) 111.

34. [1977] 2 S.C.R. 654, 13 N.R. 181, 75 D.L.R. (3d) 273.

35. Supra, footnote 4, at 766.

36. Federal Court Act, R.S.C. 1970 (2nd supp), c. 10, as amended:

S. 22(1) The Trial Division has concurrent original jurisdiction as well between subject and subject as otherwise, in all cases in which a claim for relief is made or a remedy is sought under or by virtue of Canadian maritime law or any other law of Canada relating to any matter coming within the class of subject of navigation and shipping, except to the extent that jurisdiction has been otherwise specially assigned.

S. 2 . . "Canadian maritime law" means the law that was administered by the Exchequer Court of Canada on its Admiralty side by virtue of the Admiralty Act or any other statute, or that would have been so administered if that Court had had, on its Admiralty side, unlimited jurisdiction in relation to maritime and admiralty matters, as that law has been altered by this or any other Act of the Parliament of Canada..."

37. [1979] 2 S.C.R. 157, 26 N.R. 313, 99 D.L.R. (3d) 235.

38. Supra, footnote 4, at 774 . 
aware in arriving at this conclusion that a court, in determining whether or not any particular case involves a maritime or admiralty matter, must avoid encroachment on what is in "pith and substance" a matter of local concern involving property and civil rights or any other matter which is in essence within exclusive provincial jurisdiction under s. 92 of the Constitution Act, 1867. It is important, therefore, to establish that the subject-matter under consideration in any case is so integrally connected to maritime matters as to be legitimate Canadian maritime law within federal legislative competence."

McIntyre J. concluded that cargo handling and incidental storage, performed by the carrier or by a third party under contract to the carrier, before delivery and before the goods leave the custody of a terminal operator inside the port area, was sufficiently linked to the contract of carriage by sea to be considered a maritime matter within the definition of "Canadian maritime law" in s. 22(1) of the Federal Court Act. The flexibility of the Supreme Court in their approach demonstrates a judicial recognition of the complexities of contemporary maritime matters as it would be unrealistic to decide that federal maritime jurisdiction can be amputated at one specific location in time or place. However, McIntyre J. ensured that certain limits be placed on the process by emphasizing that $:^{39}$

\footnotetext{
"... the maritime nature of this case depends upon three significant factors. The first is the proximity of the terminal operation to the sea, that is, it is within the area which constitutes the port of Montreal. The second is the connection between the terminal operator's activities within the port area and the contract of carrige by sea. The third is the fact that the storage at issue was short-term pending final delivery to the consignee. In my view, it is these factors, taken together, which characterize this case as one involving Canadian maritime law:"
}

The third requirement for jurisdiction was found in s. 91(10) of the Constitution Act, 1867, "navigation and shipping", Canadian maritime law was stated as coming within its terms. Further, the substantive content of Canadian maritime law was defined as a uniform body of federal law including both the specific principles of admiralty law and the common law principles of tort, contract and bailment used in admiralty cases. ${ }^{40}$

The dissent, given by Chouinard J., concurred in by Beetz and Lamer JJ., differed from the majority on the question of jurisdiction. They would have allowed the appeal of ITO on the grounds that the action against it was based solely on alleged delict or tort committed in Montreal, within the jurisdiction of the Quebec civil courts.

\section{THE EFFECT OF A HIMALAYA CLAUSE IN A BILL OF LADING}

After confirming Federal Court jurisdiction the Supreme Court was able to address the second issue, the effect of a Himalaya clause in a bill of lading. In the first and crucial question, whether a Himalaya clause may be effective in Canadian maritime law, McIntyre J. immediately recognized the tension between the traditional doctrine of privity of contract and the contemporary practice of marine carriage. The decision manages to maintain privity while favouring the latter consideration.

The two decisions that built a template upon which the Himalaya clause was patterned to be operative in law were surveyed. In the seminal case of

39. Supra, footnote 4, at 775-776.

40. See H.P. Glenn, Comment (1987) 66 Can. Bar Rev. 360. 
Scruttons Ltd. v. Midland Silicones Ltd. , ${ }^{41}$ the House of Lords rejected the argument of the stevedore that it should be allowed to take advantage of the carrier's limitation of liability in the bill of lading. The majority opinion affirmed the doctrine of privity; a third party stevedore could not enforce any term in the contract evidenced by the bill of lading, even if made for its benefit. Yet Lord Reid, obiter, described a situation where the third party stevedore could potentially take the benefit of an exclusion clause in the bill of lading in development of the argument, albeit unsatisfied by the drafting of the bill of lading before him, that the carrier was contracting as agent of the third party:42
"I can see a possibility of success of the agency argument if (first) the bill of lading makes it clear that the stevedore is intended to be protected by the provisions in it which limit liability, (secondly) the bill of lading makes it clear that the carrier, in addition to contracting for these provisions on his own behalf, is also contracting as agent for the stevedore that that these provisions should apply to the stevedore, (thirdly) the carrier has authority from the stevedore to do that, or perhaps later ratification by the stevedore would suffice, and (fourthly) that any difficulties about consideration moving from the stevedore were overcome."

This formed the framework of the agency construct. The fourth requirement of consideration was developed further in the Privy Council decision of New Zealand Shipping Co. Ltd. v. A.M. Satterthwaite \& Co. Ltd., ("The Eurymedon"). ${ }^{43}$ A majority, whilst reconfirming the doctrine of privity, gave validity to a Himalaya clause in a bill of lading following the four prerequisites in Scruttons. The Himalaya clause had expressly extended the exemptions of the carrier to cover, inter alia, independent contractors. The majority opinion in The Eurymedon, delivered by Lord Wilberforce, is striking in its determination to find that consideration was given by the third party principal. The reasoning used, which had to stretch the traditional principles of contract law to satisfy this fourth requirement, was that of an implied unilateral contract between the shipper-owner of the goods and the stevedore made through the medium of the agency relationship created between the carrier and the stevedore. In effect, a second legal fiction was formed based upon the initial judicial creation of the agency. The use of the unilateral contract concept in The Eurymedon has been criticized, especially because the elements of a unilateral contract do not readily apply to the relationship between the entities involved in the contract of carriage. ${ }^{44}$ The Privy Council accepted that the bill of lading formed:4s

“. . . a bargain initially unilateral but capable of becoming mutual, between the shipper and the appellant [stevedore], made through the carrier as agent. This became a full contract when the appellant performed services by discharging the goods. The performance of these services for the benefit of the shipper was the consideration for the

41. Supra, footnote 11 .

42. Id. at 474.

43. Supra, footnote 5 .

44. See, e.g. N.E. Palmer, "The Stevedore's Dilemma: Exemption Clauses and Third Parties - I and II" [1974] J.B.L. 101, 220; S. Waddams, "Comment", supra, footnote 9; W. Tetley, Marine Cargo Claims, supra, footnote 8, ch. 33 "The Himalaya Clause - Heresy or Genius" at 373; P.J. Davies and N.E. Palmer, "The Eurymedon Five Years On", [1979] J.B.L. 337; P.H. Clarke, "The Reception of The Eurymedon Decision in Australia, Canada and New Zealand" (1980) 29 I.C.L.Q. 132.

45. Supra, footnote 5, at 167-168. 
agreement by the shipper that the appellant should have the benefit of the exemptions and limitations contained in the bill of lading."

First, in the formation of a typical unilateral contract the full performance of the specified act by the promisee constitutes both its acceptance and the consideration that it provides in exchange for the promise. ${ }^{46}$ Although not expressly stated, the Privy Council appears to have separated the elements of acceptance and consideration. The statement that the bill of lading formed a "bargain initially unilateral" (emphasis added) indicates an agreement and acceptance at that point, long before the consideration is provided by the stevedore, thereby diverging from the traditional definition of a unilateral contract. . $^{7}$

Second, it has also been noted that acceptance in a unilateral contract entails full and proper performance of the act as specified in the offer. ${ }^{48}$ The Eurymedon found that the stevedore's performance in the discharge of the goods for the benefit of the shipper was sufficient consideration. However, this performance was defective in the sense that goods were damaged during discharge. In order for this determination to fit the unilateral contract form, the specified act would have to be interpreted to mean performance of the services in any manner, irrespective of the reduced quality of the performance. ${ }^{49}$

Despite these problems with The Eurymedon decision, it is adopted in the ITO Ltd. case. McIntyre J. analyzed The Eurymedon in a superficial manner only, dwelling mainly on its maintenance of the doctrine of privity of contract and its deference to commercial practice. He states: $:^{50}$

"The main support for the acceptance of the clause seems to rest upon the assertion that it accords with commercial reality and allows for the definite establishment of risks, and therefore makes certain the respective needs for the provision of insurance. It must be noted as well that Lord Wilberforce specifically refused to put his acceptance of the clause on the basis of the jus tertii. He firmly rejects any weakening of the requirement of privity for one seeking to enforce or take the benefit of a contract. It is by placing the relationship of the parties into the traditional mould of the law of contract that he finds the clause acceptable in law:"

Judicial reaffirmation of the doctrine of privity of contract in the Commonwealth has engendered both academic and judicial criticism. ${ }^{51}$ It

46. Carlill v. Carbolic Smoke Ball Co. [1893] 1 Q.B. 256; Daulia Ltd. v. Four Millbank Nominees Ltd. [1978] Ch. 231, [1978] 2 All E.R. 557 (C.A.); R. v. Ron Enrg. and Const. (Eastern) Ltd. [1981] 1 S.C.R. 111, 119 D.L.R. (3d) 267, 13 B.L.R. 72.

47. The later unanimous decision of the Privy Council in Salmond and Spraggon (A ustralia) Pty. Ltd. v. Port Jackson Stevedoring Pty. Ltd. ("The New York Star"), supra, footnote 5, gave effect to a Himalaya clause adopting the interpretation of Barwick J. in the Australian High Court who specifically split the acceptance and consideration components in the unilateral contract.

48. See, e.g., Daulia Ltd. v. Four Millbank Nominees Ltd., id., per Goff L.J. obiter at 239 where he states that generally the offeror is entitled to require full performance of the specified condition or is not bound, subject to the qualification that once the offeree starts performance the of feror is under an implied obligation not to revoke its of fer.

49. See P.H. Clarke, supra, footnote 44 , at 136-137.

50. Supra, footnote 4 , at 787.

51. See, e.g., S. Waddams, supra, footnote 15, at 212-214; S. Waddams, "Third Party Beneficiaries in the Supreme Court of Canada" (1981) 59 Can. Bar Rev. 549; J. Swan and B. Reiter, "Developments in Contract Law: The 1979-80 Term" (1981) 2 Sup. Ct. L.R. 125. Law Revision Committee, Sixth Interim Report, Cmd. 5449 (London H.M.S.O. 1937). Woodar Invt. Dev't Ltd. v. Wimpey Const. U.K. Ltd. [1980] I W.L.R. 277, [1980] I All E.R. 571 (H.L.), per Lord Scarman. 
is stated that the various exceptions and qualifications to the rule produce uncertainty in the law, that the application of the doctrine is manifestly unjust to third party beneficiaries and defeats the intentions of the contracting parties. However, the doctrine of privity is firmly reasserted by the Supreme Court in the ITO Ltd. case. This reaffirmation was not unexpected. Since the doctrine is firmly entrenched in the common law any major change must be accomplished by legislative reform. The Ontario Law Reform Commission in its 1987 Report on Amendment of the Law of Contract ${ }^{52}$, after surveying extant statutory revision, recommends the abolition of the doctrine by the enactment of a general legislative provision stating that contracts for the benefit of third parties should not be unenforceable for lack of consideration or absence of privity. ${ }^{53}$ Although general provincial jurisdiction over contracts renders uniform revision difficult, the legislatures are still the most appropriate sites for any substantial amendment to the principle. It would be impossible for the courts to effect such a change adequately, even if they desired to, in response to sporadic and factually limited opportunities.

Putting aside the issue of privity of contract, all the problems raised by The Eurymedon in finding consideration in the unilateral contract in the marine carriage relationship were termed mere "logical difficulties". .4 It is disappointing that the ITO Ltd. case did not examine them further since they may return to haunt the Courts in future cases with different facts. Instead, they are swept under the carpet in the judgment of McIntyre J. who stated that:"ss

"... conceptual difficulties of this nature are not a novel feature of the common law. In fact it may be said that one of the virtues of the common law is that it has never really let pure logic get in the way of common sense and practical necessity when a desirable result is sought to be achieved... While it may be that logical difficulties arise in the analysis developed by Lord Wilberforce, in my view it should be followed:'

In effect, the desired result justifies the distortion of the contractual principles used to reach it. Instead, the plain badges of commercial certainty and uniformity and the contractual intent of the parties are brought forth to adorn the desired result - the Supreme Court acceptance of the Himalaya clause in Canadian maritime law. The need for international uniformity, the function of the Himalaya clause in defining the location of the risks and the consequent allocation of insurance needs and the accepted practices in the marine carriage business were all persuasive. It is interesting to note that the apprehension that Canada was lagging behind other participants in the game of international commerce also spurred the decision. The Court stated that they were giving effect to the express agreement of the parties. Ironically, such an argument is rejected when raised to dispute the usual privity bar to third party enforcement of contracts made for their benefit.

52. Supra, footnote 15. See, e.g., Contracts (Privity) Act 1982, Stat. N.Z., No. 132; The Civil Code of the State of California (1985) S1559; American Law Institute, Uniform Commercial Code, Official Text (9th ed. 1978) S2-138; Quebec Civil Code, Art. 1029.

53. Supra, footnote 15, at 68-71. The alternative option, not adopted, was to recommend the enactment of a comprehensive statute detailing the rights of thrid parties and also covering subsidiary issues.

54. Id.

55. Id. 
The ITO Ltd. case barely mentioned prior Canadian decisions. Only Canadian General Electric Co. Ltd. v. Pickford and Black Ltd. ${ }^{56}$ and Greenwood Shopping Plaza Ltd. v. Beattie, ${ }^{\text {s7 }}$ the latter which appeared to approve of The Eurymedon method but could not apply it due to the particular facts, were noted and then left. Instead, the majority devoted its attention to The Eurymedon case.

\section{THE EFFECTIVENESS OF THE HIMALAYA CLAUSE IN THE ITO LTD. CASE}

The conclusion that the Himalaya clause could be effective in Canadian maritime law allowed the Court to proceed to the second question, whether the facts in the present case satisfied the four requirements for the effective operation of the Himalaya clause, clause 4 in the bill of lading between Miida and Mitsui, so that ITO could be protected by the exemption clauses therein. It is during this analysis that the phantoms of the logical difficulties discussed earlier materialize and may return to haunt future decisions.

As McIntyre J. noted, the answer depended on the construction of the two relevant contracts: the contract of carriage as evidenced by the bill of lading and the stevedore-terminal services contract between ITO and Mitsui. It was noted that Mitsui as carrier was given generous immunity in clauses 8 and 18 of the bill of lading which stated that the carrier was under no liability for any loss of the goods occurring after discharge from its vessel and imposed the risks of storage on Miida, the shipper and consignee.

The case avoids any deep examination of the four requirements of the agency construction and the relevant facts when deciding whether ITO had satisfied these prerequisites so that it could also take the benefit of the exemption clauses. McIntyre J. stated: $:^{58}$

\footnotetext{
“. . . it may be said at once that the first requirement of Lord Reid's test is met. Clause 4 of the bill of lading specifically includes stevedores and contractors. The second requirement is also met by the words of clause 4, that the carrier shall be deemed to be contracting as agent for the stevedore. The third requirement, that the carrier has authority from the stevedore to contract on its behalf, is met ..."
}

In satisfaction of the third conclusion, McIntyre J. looked to the contractual relationship previously established between Mitsui and ITO. He quoted that part of clause 7 of the stevedore-terminal services contract which stated that Mitsui would include ITO as an express beneficiary of all the exemption clauses in the contracts of carriage evidenced by bills of lading issued by Mitsui to the extent of the services ITO performed under such contracts.

McIntyre J. held that the fourth requirement, that consideration must move from the stevedore, was satisfied. He merely reiterated the finding of Lord Wilberforce in The Eurymedon, the unilateral contract model. Directly after providing The Eurymedon quote which established that consideration was provided by the stevedore in the performance of the

\footnotetext{
56. Supra, footnote 15.

57. Supra, footnote 15.

58. Supra, footnote 4, at 793.
} 
discharge services for the benefit of the shipper, ${ }^{39}$ McIntyre J. stated, "I would therefore conclude that both Mitsui and ITO are entitled to the protection of the exclusion clauses in the bill of lading, according to their tenor." ${ }^{\circ 0}$ There is no discussion or application of the particular facts in the ITO Ltd. case whatsoever. There is no examination of the fact that at least one third of the goods were stolen during storage and not delivered to Miida ${ }^{61}$ It can only be assumed that the Supreme Court considered that this did not affect the sufficiency of the consideration. It is unclear from the decision whether this resulted from the implication that ITO's performance of discharge services was sufficient consideration, the storage services being irrelevant, or from the view that, in addition, the imperfect storage contributed to the provision of consideration. It is difficult to conclude that such defective storage, if categorized as performance, could be sufficient consideration in a unilateral contract. Admittedly the unilateral contract creation is used to enable the stevedore-terminal operator to effectively exclude its liability precisely when unsatisfactory performance occurs. However, the point must be reached where performance is so defective that it would be totally unrealistic to decide that it amounts to sufficient consideration. If the Supreme Court was considering the storage services in reaching its decision, then the theft and non-delivery of at least one third of the goods during this period did not cross this boundary. One could speculate whether the Court would have come to a different conclusion if all of the goods had been stolen during storage with consequent non-delivery to Miida. Legal concepts would be completely distorted if full performance and consideration in the implied unilateral contract could be found even if all the goods were subsequently stolen during storage. Of course, if the storage aspect of ITO's obligations are eliminated from the unilateral contract mould, the entire problem of incomplete performance and insufficient consideration would be avoided because ITO appears to have discharged the goods in a satisfactory manner.

The acceptance of the Himalaya clause in the ITO Ltd. case is, however, confined to the sphere of Canadian maritime law. The particular facts of the case would appear to limit the effectiveness of a Himalaya clause to its use in a bill of lading evidencing a contract of international carriage of goods by sea. It remains to be seen whether the decision will be applied to variations on its factual theme. Would a Himalaya clause be operative if the shipper-owner of goods was not a commercial trader familiar with such a clause, but a person shipping possessions to a new place of residence? Would the clause be effective if the marine carriage of goods was not of an international character? Although not mentioned in the ITO Ltd. case, the Supreme Court of Canada has itself implicitly affirmed the use of the agency construction to permit a third party to take the benefit of a exemption clause in a totally different type of contract. In Dyck v.

59. See quote at footnote 45, cited by McIntyre J., supra, footnote 4, at 793-794.

60. Id. at 794.

61. See footnote 25 . 
Manitoba Snowmobile Association Inc. , ${ }^{62}$ the Supreme Court, per curiam, agreed with the Manitoba Court of Appeal that the third party, who was an association official in a snowmobile race, could take advantage of an exclusion clause located in the association race entry form signed by Dyck, a prospective competitor. The clause exempted the association and its officials, servants, etc. from liability caused in connection with the race. Dyck was injured when he struck the official who had stepped onto the track to signal the end of the race. The Supreme Court agreed with the Court of Appeal that the third party official was also exempted from liability because the association was acting as his agent in obtaining the waiver. The Manitoba Court of Appeal had applied The Eurymedon and the four requirements of Scruttons Ltd. in reaching its decision. The Supreme Court confirmed the Court of Appeal opinion without comment thereon. Thus it would appear that the Supreme Court, despite its narrowly phrased decision in the ITO Ltd. case, is not unwilling to extend this agency template to other contracts which are unrelated to contracts of marine carriage and even to the typical commercial contract. ${ }^{63}$ Accordingly there would be even less reason not to apply the construction to variations in the contract of carriage.

\section{CONSTRUCTION OF THE EXCLUSION CLAUSES IN THE BILL OF LADING}

The final element which McIntyre J. addressed was the question whether the exclusion clauses in the bill of lading, clause 8 in particular, could be construed to provide relief in the circumstances. Clause 8 did not expressly include negligence but was drafted in very wide language, stating, "The carrier shall not be liable in any capacity whatsoever for any . . . loss of ... the goods occurring ... . after discharge, whether awaiting shipment landed or stored . . ". ${ }^{64}$ McIntyre J. followed the approach taken by the Court of Appeal in Lamport and Holt Lines Ltd. v. Coubro and Scrutton (M. \& I.) Ltd. (The "Raphael") "s which interpreted the tripartite "test" used in Canada Steamship Lines Ltd. v. The King ${ }^{66}$ as being only a guideline for judicial construction. The Raphael stated that if an exemption clause did not exclude liability for negligence expressly, but its wording was wide and clear enough to do so by implication, the Court had to decide whether the contracting parties intended that it do so. If the only possible head of liability in the circumstances could be negligence and the parties could be

62. [1985] 1 S.C.R. 589, 18 D.L.R. (4th) 635, [1985] 4 W.W.R. 319, 35 Man. R. (2d) 22, affg j1982] 4 W.W.R. 318, 136 D.L.R. (3d) 11 (1982) 15 Man. R. (2d) 404, (C.A.). See also, D. Vaver, "Developments In Contract Law: The 1984-85 Term" (1986) 8 Supreme Court L.R. 109 , at 124-164.

63. Christian Vision Book Store Supplies (1983) Ltd. v. Avatex Management Ltd. (1987) 74 A.R. 304 (Q.B.), did not mention the ITO Lid. case but applied the Scruttons and The Eurymedon agency construction when a third party to a lease agreement claimed that the lessor had contracted on its behalf in an attempt to take the benefit of a clause in the lease. The court held that neither the first nor second of the four Scruttons case requirements were met based on the wording of the lease and the bare fact of the corporate relationship between the third party and the lessor.

64. Supra, footnote 27 .

65. [1982] 2 Lloyd's Rep. 42 (C.A.).

66. [1952] A.C. 192 (P.C.). 
deemed to have directed their minds to such an eventuality then it would not be difficult for the Court to construe that this was the intent of the parties. In contrast, if there was a head of liability in addition to negligence upon which the clause could operate, the clause would generally be construed not to cover negligence.

In implementing this process, McIntyre J. classified Mitsui as being a bailee of the goods once they were unloaded from the vessel and ITO as being a sub-bailee for value. Consequently, the duty of the bailee for value was to take reasonable care of the goods. McIntyre J. proceeded on the basis that the loss of the goods was due to ITO's negligence in storage. Clause 8, in excluding liability of the carrier in any capacity, was construed to cover liability of a bailee when loss occurred during storage. Since clause 8 did not expressly refer to negligence, McIntyre $\mathrm{J}$. proceeded to decide whether its wording could be construed to exclude it. He examined the clause in the context of the entire contract of carriage which absolved the carrier of all liability created during pre-loading or post-discharge from the vessel. Although it is an established principle of the law of contract that the Courts will take a restrictive approach to the interpretation of exemption clauses and it has been held that a clause which totally excludes liability, as here, will be construed more restrictively than a partial limitation of liability clause, ${ }^{67}$ the ITO Ltd. case does not follow this strict construction. Rather, the nature of the bailment transaction and the commercial setting of the contract with its express allocation of risk were central factors in the conclusion that negligence was effectively covered and excluded by clause 8 even though it was not specifically expressed: ${ }^{68}$

"It has been said that a general exemption from all liability will not of itself exclude
negligence. In this case, however, where the exemption clause relates only to a small part
of the full, agreed performance, such a general rule is not necessarily applicable. Here the
carrier is protected in specific terms from liability for the loss of the goods. The only duty
of the bailee is to exercise reasonable care in the safeguarding of the goods and it is
difficult to see how a loss, in this case by theft, could occur but for the negligence of the
bailee. I would therefore conclude that the words employed here are wide enough to
include negligence as being within the reasonable contemplation of the parties in
formulating their agreement ... I think it is important, in determining what was within
reasonable contemplation, to recognize this is a commercial contract between two parties
who, in essence, are determining which of them is to bear the responsibility for insurance
at the various stages of the contract."

Thus in a commercial contract where the parties are entitles of relatively equal bargaining power, the Supreme Court has taken a broad interpretation of exclusion clauses therein. The decision expressly recognizes that these entities rely on risk minimization by insurance allocation. In fact, the Court goes one step further and takes the insurance location factor into account when construing the exclusion clause. ${ }^{69}$

In conclusion, McIntyre $J$. decided that since there was no head of liability other than that of negligence upon which the exemption clause could operate, the bailee carrier Mitsui had the benefit of exclusion clause

67. Ailsa Craig Fishing Co. Ltd. v. Malvern Fishing Co. Ltd. [1983] 1 W.L.R. 964, [1983] 1 All E.R. 101 (H.L.).

68. Supra, footnote 4 , at $799-800$.

69. See, e.g. M. Baer, "The Importance of Insurance In Interpreting Exclusion Clauses" (198182) 6 Can. Bus. L.J. 97. 
8. By virtue of the operation of the Himalaya clause in clause 4 this protection was also extended to cover ITO. Therefore, neither Mitsui nor ITO were liable for the theft of the goods.

\section{CONCLUSION}

The strong reaffirmation of the doctrine of privity of contract in the ITO Ltd. case was predictable, the continuation of a principle that has grown deeply rooted in the Anglo-Canadian common law. Consequently, if the judiciary is to give relief to third parties interested in the enforcement of contractual terms any solution will have to take a convoluted path to circumvent the strictures of privity. This is illustrated by the inclusion of a Himalaya clause in a bill of lading with the twin creations of agency and unilateral contract required to effectively extend the protection of an exemption clause to a third party stevedore-terminal operator. The Court is placed in a difficult position. The international commercial context of the contract of carriage with its established practices and allocation of insurance responsibility are policy factors which can justify use of the agency route around the barrier of the doctrine of privity. Yet this comes at the expense of the purity of contractual principles. Also, a consequential problem arises - can this route be maintained when the factual setting and its connected policy elements are altered? The particular facts of the ITO $L t d$. case illustrate how distorted and artificial legal creations can become when the relationships between the players permute from case to case, even within the narrow area of the contract of international marine carriage. At some point the Court will have to halt this "house of cards" extension of legal concepts. Hopefully, the scenario of the ITO Ltd. case is located at the perimeter. 